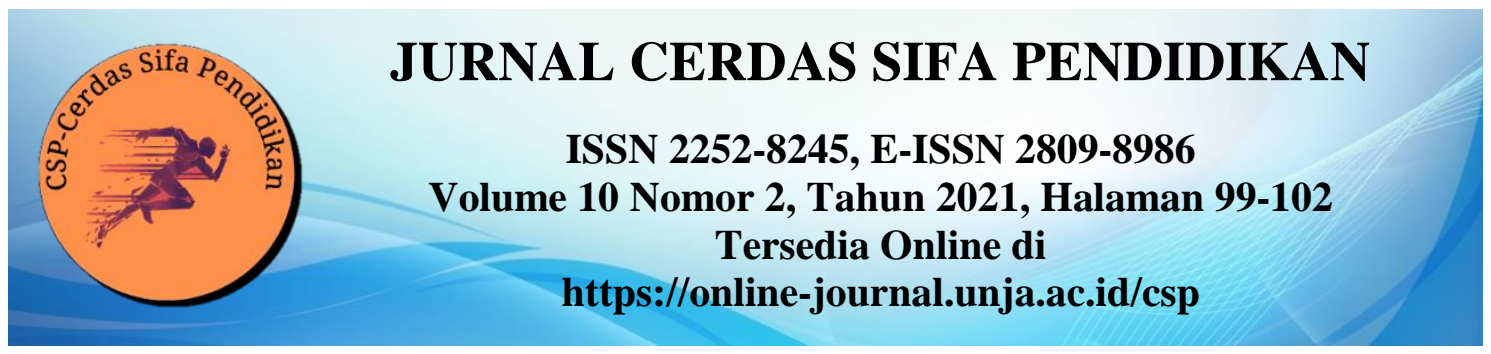

Research Article

OPEN $\bigcirc$ ACCESS

\title{
Sosialisasi Olahraga yang Aman untuk Menjaga Kebugaran Jasmani pada Masa Pandemi Covid-19 di Club Cricket UNJA
}

\author{
Anggel Hardi Yanto ${ }^{1}$, Rasyono $^{2}$ \\ Program Studi PORKES, FKIP, Universitas Jambi, Indonesia ${ }^{1}$. \\ Program Studi Kepelatihan Olahraga, FKIP, Universitas Jambi, Indonesia ${ }^{2}$.
}

Correspondence Author: rasyono@unja.ac.id

\begin{abstract}
ABSTRAK
Kehidupan masyarakat pada tahun 2021 ini, masih membawa banyak perubahan akibat pandemi covid-19. Penyebaran yang sangat cepat memaksa semua masyarakat harus dilakukan karantina. Segala bentuk aktivitas sehari-hari harus dilakukan dirumah, mulai dari belajar, bekerja, beribadah, bahkan olahragapun dianjurkan di rumah. Permasalahan mitra yaitu masih banyaknya anggota club cricket UNJA yang belum memahami dengan baik tentang olahraga yang aman untuk menjaga kebugaran jasmani di masa pandemi covid-19. Solusi yang ditawarkan yaitu mengadakan Sosialisasi tentang olahraga yang aman untuk menjaga kebugaran jasmani di masa pandemi covid19 pada club cricket UNJA dan menyusun program latihan untuk menjaga kebugaran kebugaran jasmani dengan olahraga yang aman di masa pandemi covid-19 pada club cricket UNJA
\end{abstract}

Kata Kunci: Cricket UNJA, Kebugaran

\section{Socialization of Safe Sports to Maintain Physical Fitness during the Covid-19 Pandemic at Club Cricket UNJA}

\section{ABSTRACT}

People's lives in 2021, still bring many changes due to the COVID-19 pandemic. The very fast spread forced all people to be quarantined. All forms of daily activities must be done at home, ranging from studying, working, worshiping, even sports are recommended at home. The partner problem is that there are still many UNJA cricket club members who do not understand well about safe sports to maintain physical fitness during the covid-19 pandemic. The solutions offered are holding a socialization about safe exercise to maintain physical fitness during the covid-19 pandemic at the UNJA 
cricket club and compiling an exercise program to maintain physical fitness with safe exercise during the covid-19 pandemic at the UNJA cricket club.

Keywords: Sport, Safety, physical

\section{PENDAHULUAN}

Kehidupan masyarakat pada tahun 2021 ini, masih membawa banyak perubahan akibat pandemi covid-19. Penyebaran yang sangat cepat memaksa semua masyarakat harus dilakukan karantina. Segala bentuk aktivitas sehari-hari harus dilakukan dirumah, mulai dari belajar, bekerja, beribadah, bahkan olahragapun dianjurkan di rumah. Aktivitas olahraga sebenarnya bisa dilakukan didalam ruangan maupun diluar ruangan. Namun, di masa pandemi corona, olahraga bisa dilakukan dengan pertimbangan yang cermat, masih banyaknya masyarakat yang beranggapan bahwa olahraga dapat dilaksanakan diluar rumah dengan menerapkan jarak terpisah minimal satu meter dengan orang lain dan memakai masker. Padahal tidak semua semua olahraga di luar ruangan itu aman dimasa pandemi covid-19 apalagi olahraga dengan kontak yang masif. Tak sedikit pula kegiatan olahraga yang dibatalkan dalam skala internasional (Pedersen et al, 2021:1).

\section{METODE}

Metode penyampaian materi yaitu dengan ceramah dan diskusi. Sebelum dilakukan diskusi maka terlebih dahulu dilakukan penyampaian materi dengan metode ceramah tentang pentingnya mengetahui olahraga yang aman untuk menjaga kebugaran jasmani di masa pandemi covid-19 pada club cricket UNJA. Pada kegiatan ini, tim pengabdian juga memberikan penjelasan mengenai metode ataupun cara dalam menyusun program latihan untuk menjaga kebugaran jasmani secara mandiri. berikut:

Kegiatan pengabdian pada masyarakat ini dilakukan dengan tahapan sebagai

1. Tahap awal, yaitu dilaksanakannya wawancara, observasi dan penyebaran informasi ke club cricket UNJA yakni atlet club cricket UNJA untuk mengikuti sosialisasi tentang olahraga yang aman untuk menjaga kebugaran jasmani di masa pandemi covid-19 pada club cricket UNJA.

2. Tahap kedua, yaitu tahap sosialisasi yang berlangsung sebanyak satu kali pertemuan, dengan memberikan pemaparan tentang hal-hal apa saja yang harus diperhatikan dalam menjaga kebugaran jasmani dengan olahraga yang aman, serta Menyusun program latihan.

\section{HASIL DAN PEMBAHASAN}

Masa pandemic covid-19 ini bukanlah alasan untuk bermalas-malasan untuk tidak melakukan aktifitas terutama aktivitas olahraga, karena dengan berolahraga, kebugaran dan imunitas kita akan semakin baik dalam menghadapi penyakit ataupun virus (Prayoga, 2020). Adapun manfaat olahraga yaitu dapat memberikan dampak positif terhadap kerja jantung, serta dampak psikologis sehingga memberi stimulus kepada seseorang yang berolahraga (bull et al, 2020). Olahraga meningkatkan respon sel dan sistem imun dalam hitungan detik sampai menit setelah mulai berolahraga. 
Imunitas akan terpelihara dengan baik jika berolahraga dengan rutin. Selain itu, olahraga juga dapat meningkatkan stress dapat direspon dengan lebih baik oleh tubuh. Jadi disarankan olahraga secara rutin supaya imunitas terpelihara dengan baik. Reaksi tubuh terhadap stress lebih efektif dengan kemampuan mengukur dan bereaksi dengan lebih baik (Zhu, 2020).

Demensia (Pikun) akan berkurang dengan berolahraga hal ini merupakan hasil dari beberapa penelitian. Tetapi, kelelahan, cedera juga bisa terjadi. Yang merupakan efek negatih dari olahraga (Malm, 2019). Olahraga yang dilakukan secara tepat pasti akan membawa dampak positif baik secara fisiologis maupun psikologis. Dimasa pandemi covid-19, tidak semua olahraga bisa dilaksanakan secara bebas, hal ini disebabkan karena pertimbangan protokol kesehatan yang tetap dijalankan agar terhindar dari penyebaran covid-19.

Olahraga di rumah dengan alat sederhana sangat cocok untuk meminimalkan risiko penularan dan mengurangi risiko penyakit kronis. Naik turun tangga, senam, yoga, angkat beban, sit up, push up, maupun senam qiqong juga merupakan alternatif yang baik. Olahraga tersebut hanya membutuhkan sedikit ruangan dan bisa dilakukan di setiap waktu. Video olahraga yang tersedia di internet juga bisa dimanfaatkan untuk mempertahankan kesehatan fisik dan mental selama periode kritis pandemi ini (Chen et al., 2020).

Olahraga dengan intensitas sedang sangat direkomendasikan untuk orang yang sehat. Namun cukup dengan berolahraga selama 10 menit untuk penderita infeksi saluran pernapasan atas. Olahraga sebaiknya dihentikan Jika ada perburukan gejala. Olahraga sangat tidak dianjurkan untuk penderita infeksi saluran pernapasan bawah, mengalami sakit otot, demam, dan ada gejala saluran cerna, maupun sesak napas atau gangguan organ lain. Pada masa itu Semua olahraga termasuk kompetisi/perlombaan olahraga yang intensitas tinggi harus dihentikan (Yuliana, $2020: 108$ ).

\section{SIMPULAN}

Kegiatan Sosialisasi Olahraga yang Aman Bagi Atlet di Masa Pandemi Covid-19 untuk Menjaga Kebugaran Jasmani atlet Club Cricket UNJA adalah merupakan perwujudan pengabdian kepada masyarakat yang merupakan bagian dari tugas tri dharma perguruan tinggi. Kegiatan tersebut diselenggarakan di Jurusan Pendidikan Olahraga dan Kepelatihan Universitas Jambi. Dengan jumlah peserta 15 orang. Kegiatan berlangsung sangat semangat. Antusiasme peserta sangat luar biasa. Hal itu karena materi Sosialisasi yang diberikan relevan dengan permasalahan yang dialami oleh mitra. Dan solusi yang diberikan melalui materi Sosialisasi dapat menjadi tambahan wawasan ilmu pengetahuan bagi mitra untuk diterapkan dalam proses belajar mengajar dan kehidupan atlet.

\section{DAFTAR RUJUKAN}

Bull FC, et al. 2020. World Health Organization 2020 guidelines on physical activity and sedentary behaviour $\mathrm{Br} J$ Sports Med 2020;54:1451-1462. doi:10.1136/bjsports-2020-102955

Chen. P., Mao, L., Nassis, G.P., Harmer, P., Ainsworth, B.E., Li, F. 2020. Wuhan coronavirus (2019-nCoV): The need to maintain regular physical activity while taking precautions. J Sport Health Sci., 9 (2), pp.103-4. 
Malm, C., Jakobsson, J., Isaksson A. 2019. Physical Activity and Sports $†$ Real Health Benefits: A Review with Insight into the Public Health of Sweden. Sports, 7(127), pp.1-28.

Paul M. Pedersen, Brody J. Ruihley and Bo Li. Sport and the Pandemic. 2021. by Routledge 2 Park Square, Milton Park, Abingdon, Oxon OX14 4RN and by Routledge 52 Vanderbilt Avenue, New York, NY 10017.

Prayoga, A., S. 2020. Menjaga kebugaran dan imunitas tubuh dengan bermain olahraga petanque di rumah pada masa pandemi covid 19. Prosiding SENOPATI (Seminar Olahraga Pendidikan dalam Teknologi dan Inovasi), Seri Webinar Olahraga (Training From Home), Imunitas Tubuh, dan Pandemik Covid-19 2020.

Yuliana. 2020. Olahraga yang Aman di Masa Pandemi COVID-19 untuk Meningkatkan Imunitas Tubuh. Jurnal bali membangun bali. Volume 1 Nomor 2, Agustus 2020

Zhu, W. 2020. Should, and how can, exercise be done during a coronavirus outbreak? An interview with Dr. Jeffrey A. Woods. J Sport Health Sci., 9, pp.105-7. 